\title{
Respiratory symptoms and lung function in hemp workers
}

\author{
Eugenija Zuskin, Bozica Kanceljak, Duska Pokrajac, E N Schachter, T J Witek Jr
}

\begin{abstract}
Respiratory symptoms and abnormalities of lung function were studied in 84 female and 27 male hemp workers employed in two textile mills ( $A$ and $B$ ) processing soft hemp (C sativa). In mill A 46 women and 27 men were investigated and 38 female workers were studied in mill B. Forty nine women and 30 men from a non-dusty industry served as controls. A significantly higher prevalence of almost all chronic respiratory symptoms was found in female hemp workers when compared to control workers. Among the men these differences were significant for nasal catarrh and sinusitis. A high prevalence of byssinosis was found among female hemp workers in both mills (group A, 47.8\%; group B, 57.9\%) as well as in the male workers $(66.7 \%)$. Statistically significant across shift reductions in lung function were found for all ventilatory capacity measurements in female and male hemp workers varying from $\mathbf{7 \cdot 1 \%}$ for forced expiratory volume in one second $\left(\mathrm{FEV}_{1}\right)$ to $15 \cdot 1 \%$ for flow rates at $50 \%$ vital capacity $\left(\right.$ FEF $\left._{\text {s0 }}\right)$. Measured Monday baseline values before the work shift were significantly lower than expected for hemp workers, being particularly reduced for $\mathrm{FEF}_{25}$ and $\mathrm{FEF}_{50}$. The data suggest that occupational exposure to hemp dust is a significant risk factor for the development of acute and chronic lung disease in workers employed in this textile industry.
\end{abstract}

In the early 18 th century Ramazzini ${ }^{1}$ recognised that hemp workers suffer from asthmatic symptoms due to occupational exposure to dust. More recently an asthma-like disease among hemp workers was

Andrija Stampar School of Public Health, Zagreb, Yugoslavia

E Zuskin, D Pokrajac

Institute for Medical Research and Occupational Medicine, Zagreb, Yugoslavia

B Kanceljak

Mount Sinai School of Medicine, New York, USA

E N Schachter, T J Witek described under the name cannabosis. ${ }^{23}$ Velvart et $\mathrm{al}^{4}$ reported hemp worker's disease in 34 out of 55 hemp workers and found that the severity of the disease was related to dust exposure in the workplace.

Originally the term byssinosis was limited to the description of respiratory disease in cotton workers, but the term is now also used for the asthma-like syndrome which occurs with exposure to the processing of flax, hemp, and other natural vegetable fibres. Boujuys et $a^{5}$ reported that respiratory disorders among hemp workers constitute a serious and disabling problem, particularly among those workers engaged in the batting and hackling of biologically retted soft hemp ( $C$ sativa). At about the same time Valic et $a l^{6}$ found a high prevalence of byssinotic symptoms in a group of hemp workers. These symptoms were reported by $20.0 \%$ to $62.5 \%$ of the studied workers and were frequently accompanied by across shift reductions in ventilatory capacity. Smith et $a l^{7}$ described a group of rope workers exposed to a mixed dust of hemp and flax in whom byssinotic symptoms were reported in $11.1 \%$ to $37.5 \%$ of workers. No significant difference in forced expiratory volume in one second $\left(\mathrm{FEV}_{1}\right)$ was noted between those workers exposed to high and low concentrations of dust. Valic and Zuskin ${ }^{8}$ recorded across shift reductions in ventilatory capacity on Mondays in a group of female hemp workers. These airway responses were prevented by the inhalation of metaproterenol before the work shift. Gupta et al ${ }^{9}$ demonstrated that for hemp workers who complained of respiratory diseases and had positive skin tests to hemp allergen, an improvement in respiratory symptoms and ventilatory capacity (forced vital capacity (FVC) and $\mathrm{FEV}_{1}$ ) was brought about by specific immunotherapy. Chen ${ }^{10}$ reported 31 workers with symptoms of asthma among 242 hemp workers studied. The same author observed a correlation between positive skin tests and increased immunoglobulin $\mathrm{E}$ concentrations in these workers.

Comparative studies of prevalence of respiratory symptoms in workers exposed to different textile dusts indicate that hemp and flax dust are more potent than cotton dust in producing byssinotic symptoms. ${ }^{11}$ Bouhuys et al ${ }^{12}$ in a study of Spanish hemp workers described an extremely high prevalence of chronic respiratory symptoms 
including cough, phlegm, and dyspnoea. Many of the workers showed irreversible loss of pulmonary function when compared to a control group of the same age. Ninety one per cent of the hemp workers had a history of Monday dyspnoea while working with hemp. Bouhuys and Zuskin ${ }^{13}$ studied this cohort over a seven year follow up period. They showed that hemp workers with more than 20 years of exposure had a significantly higher occurrence of chronic cough, phlegm, dyspnoea, and a significantly larger annual decline in $\mathrm{FEV}_{1}$ than the control subjects.

The goal of the present study of hemp workers was to establish current prevalence of respiratory symptoms in this industry and to better characterise abnormalities of ventilatory capacity in hemp workers.

\section{Subjects and methods}

Two groups of female hemp workers employed in two different mills (46 in mill A (group A), 38 in mill B (group B)) and a group of 27 male hemp workers employed in mill A were included in the study. All workers were currently employed in the processing of hemp fibres in the areas of carding and spinning. The hemp processed in these industries was ultimately used for the manufacture of rope, firehose, rugs, and clothing. Workers in both mills frequently rotated jobs so that they were exposed to all phases of the processing. The mean age of the women in group A was 39 (range 19-63) with a mean exposure of 15 (range 1-36) years. For the women of group B the mean age was 40 (range 21-55) with a mean exposure of 16 (range 2-33) years. The group of male hemp workers had a mean age of 43 (range 22-52) and a mean exposure of 20 (range 6-30) years. The women were mostly non-smokers $(83 \%$ in mill $\mathrm{A}$ and $89 \%$ in mill B) whereas the men were predominantly smokers ( $92 \%$; average 20 cigarettes daily). A group of 49 female control workers and 30 male control workers were included in the study. The age, smoking habits, and duration of employment of the controls were similar to those of the hemp workers. The control workers were employed as packers in the food industry with no exposure to noxious dusts or fumes.

\section{RESPIRATORY SYMPTOMS}

Respiratory symptoms were documented using a modification of the Medical Research Council Committee questionnaire on respiratory symptoms with additional questions on byssinosis. ${ }^{14}{ }^{15}$ In all workers a detailed occupational and smoking history was recorded. Specific symptoms were defined as follows:

chronic cough or phlegm-cough or phlegm production or both for at least three months a year; chronic bronchitis-cough and phlegm for a minimum of three months a year and for not less than two successive years; dyspnoea grades, grade 3shortness of breath when walking with other people at an ordinary pace on level ground, grade 4shortness of breath when walking at their own pace on level ground; occupational asthma-recurring attacks of dyspnoea, chest tightness, wheezing, and impairment of pulmonary function of the obstructive type diagnosed by physical examination and spirometric measurements during exposure to dust at or after work $^{16}$; byssinosis grades, $1 / 2$-occasional chest tightness on Monday; 1 -chest tightness and or difficulty in breathing or both on Mondays only, 2chest tightness or difficulty in breathing or both on Mondays and other work days.

Acute symptoms that developed during a work shift were also recorded for all workers. Symptoms comprised cough, irritation or dryness of the throat, secretions, dryness or bleeding of the nose, eye irritation, and headache.

\section{VENTILATORY CAPACITY STUDIES}

Ventilatory capacity was measured by recording maximum expiratory flow volume (MEFV) curves on a Pneumoscreen spirometer (Jaeger, Federal Republic of Germany). Work shift changes in ventilatory capacity were measured by recording MEFV curves on Monday before ( $6.00 \mathrm{am})$ and after $(2.00$ pm) a work shift. From MEFV curves the forced vital capacity (FVC), the forced expiratory volume in one second $\left(\mathrm{FEV}_{1}\right)$, and flow rates at $50 \%$ and $25 \%$ vital capacity $\left(\mathrm{FEF}_{50}, \mathrm{FEF}_{25}\right)$ were measured. Monday preshift values were compared with expected values established by the Commission des Communautés Européennes (CECA $)^{17}$ for FVC and $\mathrm{FEV}_{1}$, with normal values described by Cherniack and $\operatorname{Raber}^{18}$ for $\mathrm{FEF}_{50}$ and $\mathrm{FEF}_{25}$.

\section{ENVIRONMENTAL DUST MEASUREMENTS}

Airborne dust was sampled during an eight hour work shift in the workplace of the examined workers. Casella personal samplers with millipore field monitors and millipore AA membrane filters were used to estimate total exposure to dust. In addition two stage stationary samplers consisting of a membrane filter preceded by a horizontal elutriator were used to collect the respirable fraction.

ENVIRONMENTAL BACTERIAL ANALYSIS

Agar plates were placed in the work environment to collect bacterial flora in the work areas.

\section{STATISTICAL ANALYSIS}

Measurements of ventilatory capacity were analysed using the $t$ test for differences of paired (across shift changes) and unpaired (comparing baseline to predicted values) variables. The $\chi^{2}$ test and Fisher's exact test were used for testing differences in the prevalence of respiratory symptoms; $p<0.05$ was considered statistically significant. 


\section{Results}

RESPIRATORY SYMPTOMS

Table 1 shows the prevalence of chronic respiratory symptoms for the two groups of women and for the male hemp workers and the control workers. There were no significant differences in the prevalence of chronic respiratory symptoms between groups $A$ and $B$ of female hemp workers. By comparison with the control group, a significantly higher prevalence of all chronic respiratory symptoms was found for women in group $B(p<0.01)$ and for chronic cough, dyspnoea, nasal catarrh and sinusitis $(p<0.01)$, and asthma $(p<0.05)$ for women in group A. For the male hemp workers the differences between the exposed and the control workers were significant only for nasal catarrh $(\mathrm{p}<0.05)$ and sinusitis $(\mathrm{p}<$ 0.01 ).

A high prevalence of byssinosis was found in both groups of female hemp workers (A, 47.8\%; B, $57.9 \%$ ) and among male hemp workers $(66.7 \%$ ) (table 1). These symptoms were analysed by grades of byssinosis. For female hemp workers the highest prevalence was recorded for byssinosis grade 1 (A, $19.6 \%$; B, 31.6\%) followed by grade $2(\mathrm{~A}, 19.6 \%$; , $22 \cdot 2{ }_{0}$ ) and grade $1 / 2(A, 10.9 \%$;, $5.3 \%)$. In male hemp workers $44.4 \%$ had byssinosis grade $1,22.2 \%$ had grade 2 , and none had grade $1 / 2$. Byssinotic symptoms were not found among control workers of either sex.

A high prevalence of acute symptoms during the work shift was recorded in female and in male hemp workers (table 2). The highest prevalence of these acute symptoms was recorded for eye irritation, cough, and dryness of the throat and nose.

\section{VENTILATORY CAPACITY STUDIES}

Table 3 presents mean across shift changes in ventilatory capacity in the two groups of female workers (A and B). Statistically significant across shift reductions $(p<0.01)$ were similar for women from both mills. These across shift changes were largest (expressed as per cent change from baseline) for $\mathrm{FEF}_{50} \quad(\mathrm{~A}=10.4 \% ; \quad \mathrm{B}=9.4 \%)$ and $\mathrm{FEF}_{25}$ $(A=13.4 \% ; \quad B=14.8 \%)$ followed by FVC

Table 1 Prevalence of chronic respiratory symptoms in hemp workers and controls

\begin{tabular}{|c|c|c|c|c|c|c|c|c|c|c|}
\hline \multirow[b]{2}{*}{ Group } & \multirow[b]{2}{*}{$\begin{array}{l}\text { Mean } \\
\text { age } \\
(y)\end{array}$} & \multirow[b]{2}{*}{$\begin{array}{l}\text { Mean } \\
\text { exposure } \\
(y)\end{array}$} & \multicolumn{8}{|l|}{$\begin{array}{l}\text { No with } \\
\left(\begin{array}{c}0 \\
0\end{array}\right)\end{array}$} \\
\hline & & & $\begin{array}{l}\text { Chronic } \\
\text { cough }\end{array}$ & $\begin{array}{l}\text { Chronic } \\
\text { phlegm }\end{array}$ & $\begin{array}{l}\text { Chronic } \\
\text { bronchitis }\end{array}$ & $\begin{array}{l}\text { Dyspnoea } \\
\text { grades } \\
2 \mathcal{E} 3\end{array}$ & Asthma & $\begin{array}{l}\text { Nasal } \\
\text { catarrh }\end{array}$ & Sinusitis & Byssinosis \\
\hline \multicolumn{11}{|c|}{ Women } \\
\hline $\begin{array}{l}\text { Hemp A } \\
(n=46) \\
\text { Hemp B } \\
(n=38) \\
\text { Controls } \\
(n=49)\end{array}$ & $\begin{array}{l}39 \\
40 \\
30\end{array}$ & $\begin{array}{l}15 \\
16 \\
15\end{array}$ & $\begin{array}{l}26^{\star \star} \\
(56 \cdot 5) \\
19 \star \star \\
(50 \cdot 0) \\
6 \\
(12 \cdot 2)\end{array}$ & $\begin{array}{c}9 \\
(19 \cdot 6) \\
7 \star \star \\
(18 \cdot 4) \\
4 \\
(8 \cdot 2)\end{array}$ & $\begin{array}{c}9 \\
(21 \cdot 7) \\
8^{\star \star} \\
(18 \cdot 4) \\
4 \\
(8 \cdot 2)\end{array}$ & $\begin{array}{c}16^{\star \star} \\
(34 \cdot 8) \\
7 \star \star \\
(21 \cdot 1) \\
2 \\
(4 \cdot 1)\end{array}$ & $\begin{array}{l}4^{\star} \\
(8 \cdot 7) \\
8^{\star \star} \\
(21 \cdot 1) \\
0\end{array}$ & $\begin{array}{l}16^{\star \star} \\
(34 \cdot 8) \\
17^{\star \star} \\
(44 \cdot 7) \\
5 \\
(10 \cdot 2)\end{array}$ & $\begin{array}{l}12^{\star \star} \\
(26 \cdot 1) \\
19 \star \star \\
(50 \cdot 0) \\
3 \\
(6 \cdot 1)\end{array}$ & $\begin{array}{l}22^{\star \star} \\
(47 \cdot 8) \\
22^{\star \star} \\
(57 \cdot 9) \\
0\end{array}$ \\
\hline \multicolumn{11}{|c|}{ Men } \\
\hline $\begin{array}{l}\text { Hemp } \\
(n=27) \\
\text { Controls } \\
(\mathbf{n}=30)\end{array}$ & $\begin{array}{l}43 \\
42\end{array}$ & 20 & $\begin{array}{l}13 \\
(48 \cdot 1) \\
11 \\
(36 \cdot 7)\end{array}$ & $\begin{array}{l}11 \\
(40 \cdot 7) \\
10 \\
(33 \cdot 3)\end{array}$ & $\begin{array}{l}11 \\
(40 \cdot 7) \\
10 \\
(33 \cdot 3)\end{array}$ & $\begin{array}{c}7 \\
(25 \cdot 9) \\
3 \\
(11 \cdot 1)\end{array}$ & $\begin{array}{l}2 \\
(7 \cdot 4) \\
0\end{array}$ & $\begin{array}{c}7^{\star} \\
(25 \cdot 9) \\
2 \\
(6 \cdot 7)\end{array}$ & $\begin{array}{c}9 \star \star \\
(33 \cdot 3) \\
2 \\
(6 \cdot 7)\end{array}$ & $\begin{array}{l}18^{\star \star} \\
(66 \cdot 7) \\
0\end{array}$ \\
\hline
\end{tabular}

Difference between exposed and control workers statistically significant, ${ }^{\star} p<0.05 ;{ }^{\star \star} p<0.01$.

Table 2 Prevalence of acute symptoms during the work shift in female and male hemp workers

\begin{tabular}{|c|c|c|c|c|c|c|c|c|}
\hline \multirow[b]{3}{*}{ Group } & \multicolumn{8}{|l|}{$\begin{array}{l}\text { No with } \\
\left(\begin{array}{c}o \\
o\end{array}\right)\end{array}$} \\
\hline & \multirow[b]{2}{*}{ Cough } & \multicolumn{2}{|l|}{ Throat } & \multicolumn{3}{|l|}{ Nose } & \multirow{2}{*}{$\begin{array}{l}\text { Eye } \\
\text { irritation }\end{array}$} & \multirow[b]{2}{*}{ Headache } \\
\hline & & Irritation & Dryness & Secretion & Dryness & Bleeding & & \\
\hline \multicolumn{9}{|c|}{ Women } \\
\hline $\begin{array}{l}\text { Hemp A } \\
(n=46) \\
\text { Hemp B } \\
(n=38)\end{array}$ & $\begin{array}{l}36 \\
(78 \cdot 3) \\
31 \\
(81 \cdot 6)\end{array}$ & $\begin{array}{l}24 \\
(52 \cdot 2) \\
27 \\
(71 \cdot 1)\end{array}$ & $\begin{array}{l}29 \\
(63 \cdot 0) \\
31 \\
(81 \cdot 6)\end{array}$ & $\begin{array}{l}17 \\
(36 \cdot 9) \\
10 \\
(26 \cdot 3)\end{array}$ & $\begin{array}{l}24 \\
(52 \cdot 2) \\
23 \\
(60 \cdot 5)\end{array}$ & $\begin{array}{l}21 \\
(45 \cdot 7) \\
6 \\
(15 \cdot 8)\end{array}$ & $\begin{array}{l}36 \\
(78 \cdot 3) \\
32 \\
(84 \cdot 2)\end{array}$ & $\begin{array}{l}33 \\
(71 \cdot 7) \\
26 \\
(68 \cdot 4)\end{array}$ \\
\hline \multicolumn{9}{|c|}{ Men } \\
\hline $\begin{array}{l}\text { Hemp } \\
(n=27)\end{array}$ & $\begin{array}{l}22 \\
(81 \cdot 5)\end{array}$ & $\begin{array}{l}17 \\
(62 \cdot 9)\end{array}$ & $\begin{array}{l}19 \\
(70 \cdot 3)\end{array}$ & $\begin{array}{c}8 \\
(29 \cdot 6)\end{array}$ & $\begin{array}{l}15 \\
(55 \cdot 6)\end{array}$ & $\begin{array}{l}13 \\
(48 \cdot 1)\end{array}$ & $\begin{array}{l}22 \\
(81 \cdot 5)\end{array}$ & $\begin{array}{l}15 \\
(55 \cdot 6)\end{array}$ \\
\hline
\end{tabular}


Table 3 Across shift changes in ventilatory capacity in female hemp workers

\begin{tabular}{|c|c|c|c|c|c|c|}
\hline \multirow[b]{3}{*}{ Test } & \multicolumn{3}{|c|}{ Hemp Group A $(n=46)$} & \multicolumn{3}{|c|}{ Hemp Group B $(n=38)$} \\
\hline & \multirow{2}{*}{$\begin{array}{l}\text { Before } \\
\text { shift } \\
\text { mean (SD) }\end{array}$} & \multicolumn{2}{|l|}{ Difference } & \multirow{2}{*}{$\begin{array}{l}\text { Before } \\
\text { shift } \\
\text { mean (SD) }\end{array}$} & \multicolumn{2}{|l|}{ Difference } \\
\hline & & Before-after & p Value & & Before-after & p Value \\
\hline $\begin{array}{l}\mathrm{FVC}_{(1)} \\
\mathrm{FEV}_{1}(1) \\
\mathrm{FEF}_{\mathbf{~} 0}(1 / \mathrm{s}) \\
\mathrm{FEF}_{25}(1 / \mathrm{s})\end{array}$ & $\begin{array}{l}3.52(0.52) \\
2.77(0.45) \\
4.05(0.79) \\
1.79(0.61)\end{array}$ & $\begin{array}{l}-0.31(-8.8 \%)^{\star} \\
-0.25(-9.0 \%) \\
-0.42(-10.4 \%) \\
-0.24(-13.4 \%)\end{array}$ & $\begin{array}{l}<0.01 \\
<0.01 \\
<0.01 \\
<0.01\end{array}$ & $\begin{array}{l}3.50(0.65) \\
2.73(0.54) \\
3.95(1.06) \\
1.76(0.60)\end{array}$ & $\begin{array}{l}-0.21(-6.0 \%) \\
-0.22(-8.1 \%) \\
-0.37(-9.4 \%) \\
-0.26(-14.8 \%)\end{array}$ & $\begin{array}{l}<0.01 \\
<0.01 \\
<0.01 \\
<0.01\end{array}$ \\
\hline
\end{tabular}

$\star$ Decrease as percentage of baseline measurement.

$(\mathrm{A}=8.8 \% ; \quad \mathrm{B}=6.0 \%)$ and $\mathrm{FEV}_{1} \quad(\mathrm{~A}=9.0 \%$; $\mathrm{B}=8 \cdot 1 \%$ ). There was no difference in the magnitude of across shift reductions of FVC and FEV between $_{1}$ female workers with and without byssinosis. Among byssinotic subjects (group A and B combined, $\mathrm{n}=88$ ), however, the mean across shift reductions for $\mathrm{FEF}_{50}(-12.9 \%)$ and $\mathrm{FEF}_{25}(-16.0 \%)$ were greater than for non-byssinotic subjects $\left(\mathrm{FEF}_{50},-5.4 \%\right.$; $\left.\mathrm{FEF}_{25},-9 \cdot 2 \%\right)$ and these differences were statistically significant $(p<0.05)$.

Figure 1 shows the mean baseline data for ventilatory capacity (measured pre shift on Monday morning) in relation to expected normal values, separately in female workers with and without byssinosis (groups A and B combined). All mean measures of ventilatory function in female hemp workers were significantly lower $(p<0.01)$ than expected, being particularly reduced for $\mathrm{FEF}_{25}$. The mean $\mathrm{FEF}_{25}$ was $69 \%$ of that predicted in workers

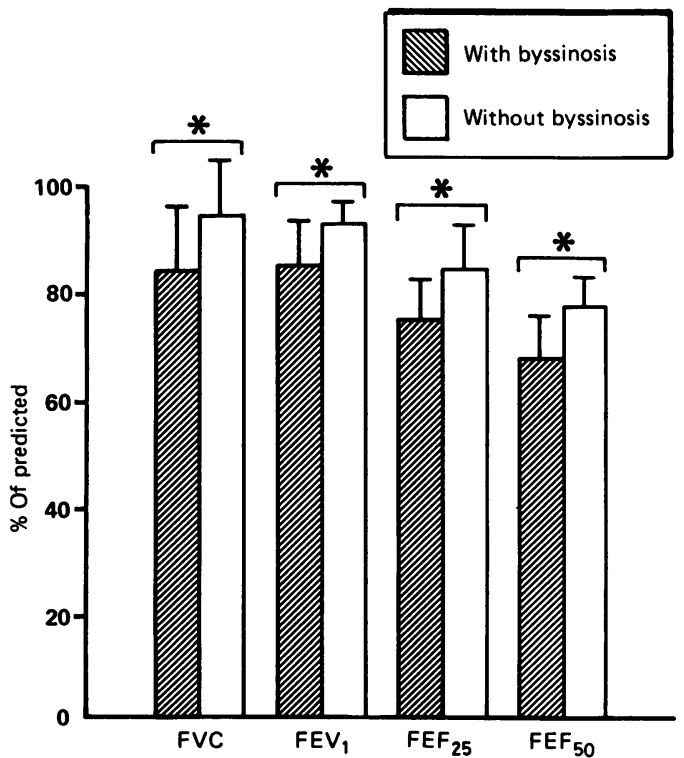

Figure 1 Mean Monday preshift FVC, FEV,$F E F_{50}$, and $F E F_{25}$ expressed as per cent of predicted (SE) in 44 female hemp workers with and 40 without byssinosis. * Significantly different $(p<0.01)$. with, and $75 \%$ of that predicted in workers without byssinosis. By analysing individual data in relation to normal values, three (3.4\%) had FVC, seven (8.3\%) had $\mathrm{FEV}_{1}, 13(15.5 \%)$ had $\mathrm{FEF}_{50}$, and $11(13.1 \%)$ had $\mathrm{FEF}_{25}$ below $80 \%$ but greater than $70 \%$ of expected values. The number of female hemp workers in groups $\mathrm{A}$ and $\mathrm{B}$ that had $\mathrm{FEF}_{50}$ and $\mathrm{FEF}_{25}$ below $70 \%$ of normal values was $14(16 \cdot 7 \%)$ for $\mathrm{FEF}_{50}$ and $36(42 \cdot 9 \%)$ for $\mathrm{FEF}_{25}$.

Table 4 presents data for ventilatory capacity in 27 male hemp workers. There were statistically significant across shift reductions in all measurements of ventilatory capacity $(p<0.01)$. These reductions were the greatest when measured by FEF $_{50}$ $(-15 \cdot 1 \%)$, followed by $\mathrm{FEF}_{25}(-14.6 \%), \mathrm{FEV}_{1}$ $(-9.3 \%)$ and FVC $(-7 \cdot 1 \%)$. Figure 2 shows the mean measured baseline (Monday preshift) values for the male workers. These were significantly less than predicted. Analysis of the individual measured data in relation to normal values showed that three $(11.1 \%)$ had FVC, one $(3.7 \%)$ had $\mathrm{FEV}_{1}$, three $(11.1 \%)$ had $\mathrm{FEF}_{50}$, and four $(18.5 \%)$ had $\mathrm{FEF}_{25}$ below $80 \%$ but greater than $70 \%$ of the expected values. A larger number of workers had measured values of $70 \%$ or less than expected $(F V C=3$ $(11 \cdot 1 \%), \mathrm{FEV}_{1}=6(22 \cdot 2 \%), \mathrm{FEF}_{50}=7(25.9 \%)$, $\mathrm{FEF}_{25}=10(37.0 \%)$. All of these workers had symptoms of byssinosis.

Table 5 shows data for ventilatory capacity in 12 female hemp workers with occupational asthma. Significant reductions over the work shift were recorded for $\mathrm{FEV}_{1}, \mathrm{FEF}_{50}$ and $\mathrm{FEF}_{25}(\mathrm{p}<0.01)$. In relation to predicted values, values for baseline lung function(FVC, $82.9 \% ; \mathrm{FEV}_{1}, 76.7 \% ; \mathrm{FEF}_{50}, 61.7 \%$; $\mathrm{FEF}_{25}, 60.9 \%$ ) were significantly lower for all tests.

Table 4 Across shift changes in ventilatory capacity in 27 male hemp workers

\begin{tabular}{|c|c|c|c|}
\hline \multirow[b]{2}{*}{ Test } & \multirow{2}{*}{$\begin{array}{l}\text { Before } \\
\text { shift } \\
\text { mean (SD) }\end{array}$} & \multicolumn{2}{|l|}{ Difference } \\
\hline & & Before-after & p Value \\
\hline $\begin{array}{l}F V C(1) \\
F V_{1}(1) \\
F(1 / s) \\
F F_{25}(1 / s)\end{array}$ & $\begin{array}{l}4.23(1.01) \\
3.22(0.99) \\
4.44(1.90) \\
2.05(0.85)\end{array}$ & $\begin{array}{l}-0.30(-7.1 \%)^{\star} \\
-0.30(-9.3 \%) \\
-0.67(-15.1 \%) \\
-0.30(-14.6 \%)\end{array}$ & $\begin{array}{l}<0.01 \\
<0.01 \\
<0.01 \\
<0.01\end{array}$ \\
\hline
\end{tabular}

*Decrease as percentage of baseline measurement. 


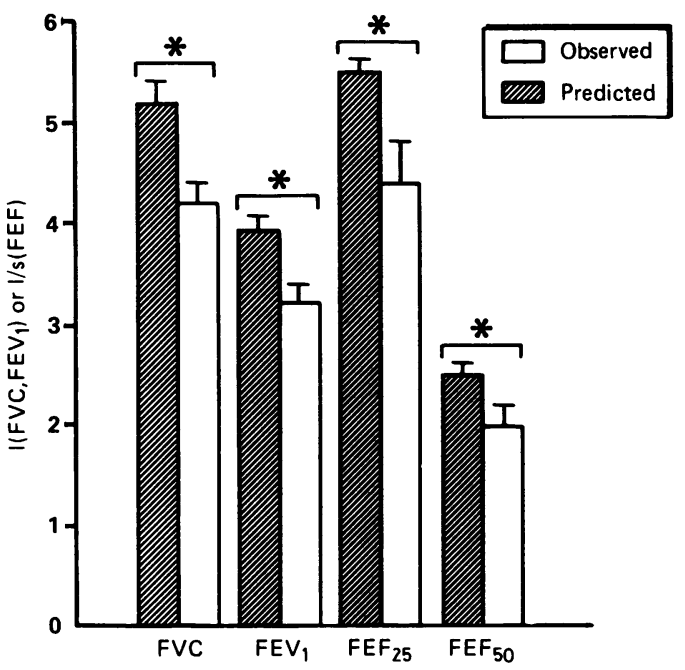

Figure 2 Mean observed and predicted Monday preshift $F V C, F E V_{1}, F E F_{50}$, and $F E F_{25}(S E)$ in 27 male hemp workers. * Significantly different $(p<0.01)$.

Table 5 Ventilatory capacity and across shift changes in female hemp workers with asthma $(n=12)$

\begin{tabular}{|c|c|c|c|c|}
\hline \multirow[b]{2}{*}{ Test } & \multirow{2}{*}{$\begin{array}{l}\text { Observed } \\
\text { (before shift) } \\
\text { mean (SD) }\end{array}$} & \multirow[b]{2}{*}{ p Value $\dagger$} & \multicolumn{2}{|l|}{ Difference } \\
\hline & & & Before-after & p Value \\
\hline $\begin{array}{l}\text { FVC } \\
\text { FEV }_{1} \\
\text { FEF }_{50} \\
\text { FEF }_{25}\end{array}$ & $\begin{array}{l}3.06(0.76)(82.9 \%)^{\star} \\
2.24(0.71)(76.7 \%) \\
2.78(0.16)(61.7 \%) \\
1.39(0.85)(60.9 \%)\end{array}$ & $\begin{array}{l}<0.01 \\
<0.01 \\
<0.01 \\
<0.01\end{array}$ & $\begin{array}{l}-0.08(-2.6 \%) \\
-0.21(-9.4 \%) \\
-0.20(-7.2 \%) \\
-0.21(-15.1 \%\end{array}$ & $\begin{array}{l}\ddagger<0.01 \\
<0.01 \\
<0.01 \\
<<0.01\end{array}$ \\
\hline
\end{tabular}

*Lung function as percentage of predicted.

tLevel of significance for observed-predicted.

$\ddagger$ Decrease as percentage of baseline measurement.

ENVIRONMENTAL DUST MEASUREMENTS

The mean total concentration of hemp dust was 22.35 (range $3 \cdot 3-68.5$ ) $\mathrm{mg} / \mathrm{m}^{3}$ with a mean respirable fraction of 9.93 (range $1.3-38.4$ ) $\mathrm{mg} / \mathrm{m}^{3}$. These measurements are much greater than the maximum allowable concentration for vegetable textile dust allowed by Yugoslav occupational standards (total dust, $5 \mathrm{mg} / \mathrm{m}^{3}$; respirable fraction, $1 \mathrm{mg} / \mathrm{m}^{3}$ ). This may be compared to the United States standard for cotton dust which requires concentrations of $0.2 \mathrm{mg} /$ $\mathrm{m}^{3}$ or less.

\section{ENVIRONMENTAL BACTERIAL ANALYSIS}

Results of bacterial sampling in the work environment showed the presence of several different bacterial species including Enterobacter aerogenes, Citrobacter, Pseudomonas aeruginosa, Staphylococcus albus, Escherichia coli, Proteus mirabilis, Enterobacter cloacae, and Enterococcus.

\section{Discussion}

Our data show that exposure to hemp dust is associated with the development of a high prevalence of acute and chronic respiratory symptoms. These data are similar to previous observations by Barbero and Flores who also found high prevalence of chronic respiratory symptoms among active and retired hemp workers. ${ }^{21920}$ This group also found that many hemp workers die at an early age presumably as a consequence of their exposure.

The prevalence of byssinosis among our hemp workers is high and similar to that previously reported by Valic et al who described byssinosis prevalences ranging from $15 \cdot 1{ }^{\circ}$ o to $40 \cdot 6^{\circ}{ }_{0}{ }^{6}{ }^{6}$ The same authors also described significant reductions in ventilatory capacity across the work shift. A high prevalence of byssinosis was also described by Bouhuys $e t$ al who reported a byssinosis prevalence of $77 \%$ among Spanish hemp workers. ${ }^{5}$

By studying the effect of different vegetable dusts on workers Valic and Zuskin concluded that the highest prevalences of byssinosis grades were found for hemp $\left(44^{\circ}{ }_{0}\right)$ and flax workers $(43 \%)$ followed by cotton workers $\left(27^{\circ}{ }_{0}\right) .^{11}$ The prevalence of other chronic respiratory symptoms was also highest among hemp workers, followed by flax and cotton workers. The significantly higher prevalences of most chronic respiratory symptoms in hemp workers suggests that exposure to hemp dust is an important contributor to occupational airway disease. Importantly, Valic and Zuskin have demonstrated that in hemp workers byssinosis symptoms develop after an exposure as short as one to two years. ${ }^{8}$

Acute symptoms noted during the work shift were very common in this study; by contrast in a previous study of workers not exposed to airway irritants only two workers $\left(9 \cdot 5^{\circ}{ }_{0}\right)$ complained of cough and one $\left(4 \cdot 8^{\circ}{ }_{0}\right)$ of headache occasionally during the work shift. ${ }^{21}$ This observation of frequent symptoms and marked changes across the work shift suggests that either hemp dust is a very potent airway irritant or that the industries concerned with the processing of this vegetable product are significantly more dusty (or less well regulated) than comparable non-hemp mills.

The acute byssinotic effects of exposure to hemp dust are well documented by the magnitude of the $\mathrm{FEV}_{1}$ and particularly the $\mathrm{FEF}_{50}$ and the $\mathrm{FEF}_{25}$ changes during the Monday work shift. In our study the acute decreases in $\mathrm{FEF}_{50}$ and $\mathrm{FEF}_{25}$ were more pronounced than those in $\mathrm{FEV}_{1}$. Bouhuys et al showed that respiratory disease among hemp workers is a serious and disabling illness, particularly among those engaged in batting and hackling of biologically retted soft hemp (C sativa). ${ }^{5}$ That the dust developed during hemp batting has potent bronchoconstrictor properties was also shown by the development within one hour of dust exposure of 
chest tightness, cough, and dyspnoea in healthy subjects whose $\mathrm{FEV}_{1}$ decreased from 4.33 to 3.681 during this exposure.

Recent studies indicate that chronic lung disease in the form of intractable symptoms and irreversible changes in lung function is an integral part of byssinosis. ${ }^{22} 23$ Cross sectional as well as prospective studies among textile workers indicate higher prevalences of chronic symptoms and an accelerated loss of lung function in textile workers independent of their smoking exposure. ${ }^{1324}$ In the current study we document an excess of chronic symptoms and abnormal lung function that relate specifically to Monday prework shift measurements and thus exclude possible across shift contributions to these measurements. Finally, most workers in our cohort were non-smoking women suggesting that the effect on baseline lung function is a result of exposure to dust rather than tobacco smoke.

Endotoxin has been implicated as a possible causative agent in the pathogenesis of byssinosis. ${ }^{25}$ Our microbiological studies of air quality show the presence of many organisms in the hemp workplace, in particular gram negative bacteria. Nevertheless, the role of endotoxin in byssinosis remains to be more fully defined. ${ }^{26}$

Our study showed a very high prevalence of acute and chronic respiratory symptoms and changes in ventilatory capacity in workers employed in the hemp industry in Yugoslavia. We suggest that hemp workers in small poorly regulated mills are at a high risk for acute or chronic lung disease or both. This risk is amplified by the chronic nature of the exposure because retention of workers in these small industries tends to be high. As in other industries prone to byssinosis, pre-employment medical examinations and medical surveillance as well as more stringent industrial hygiene control measures are necessary to safeguard the health of textile workers. Tests of lung function should be performed before and after a work shift by recording $\mathrm{FEV}_{1}$ or MEFV curves on a regular basis. Such examinations allow an assessment of risk in this industry and the identification of sensitive workers who should be followed up. In the case of progressive impairment of lung function or the development of respiratory symptoms, workers should be moved from dusty areas, which carry a high risk of respiratory disease.

The research was supported in part by grant No YF 733 from the National Institutes of Health, Bethesda, Md, USA; grant No RO1 OHO 25593 01Al from the National Institute of Occupational Safety and
Health; and the Henry and Catherine Gaisman and the Miller Foundations, New York, NY, USA.

1 Ramazzini B. De Morbis Artificum Diatriba (translation and notes by Wright, $W C$ ) Chicago: University Press, 1940.

2 Barbero C, Flores R. Enfermedad del canamo. Rev Clin Esp 1944;13:395-9.

3 Jimenez DC, Lahoz C. Cannabosis (enfermedad de los trabajadores del canamo). Rev Clin Esp 1944;14:366-76.

4 Velvart J, Stavrovska O. Zdravotny stav zamestnancov pri spracovavani konopi. Pracovni Lekarstvi (Praha) 1963;15: 153-7.

5 Bouhuys A, Barbero A, Lindell SE, Roach SA, Schilling RSF. Byssinosis in hemp workers. Arch Environ Health 1967; 14:533-44.

6 Valic F, Zuskin E, Walford J, Kersic W, Paukovic R. Byssinosis, chronic bronchitis and ventilatory capacities in workers exposed to soft hemp dust. Br J Ind Med 1968;25:176-86.

7 Smith GF, Coles GV, Schilling RSF, Walford J. A study of rope workers exposed to hemp and flax. Br J Ind Med 1969;26: 109-14.

8 Valic F, Zuskin E. Effects of hemp dust exposure on nonsmoking female textile workers. Arch Environ Health 1971;23:359-64.

9 Gupta BN, Mehrotra NK, Clerk SH, et al. Immunotherapy in hemp workers having respiratory complaints. Indian $\mathrm{J}$ Med Sci 1980;34:72-81.

10 Chen KZ. Occupational asthma induced by sisal hemp. National Medical Journal of China 1986;5:282-5.

11 Valic F, Zuskin E. Effects of different vegetable dust exposure. Br J Ind Med 1972;29:293-7.

12 Bouhuys A, Barbero A, Schilling RSF, et al. Chronic respiratory disease in hemp workers. Am J Med 1969;46:526-37.

13 Bouhuys A, Zuskin E. Chronic respiratory disease in hemp workers. Ann Intern Med 1976;84:398-405.

14 Medical Research Council Committee on Etiology of Chronic Bronchitis. Standardised questionnaire on respiratory symptoms. Br Med J 1960;2:1665.

15 Schilling RSF, Vigliani EC, Lemmers B, Valic F. A report on a conference on byssinosis. Madrid: XIV International Congress on occupational health, 1963:137-44.

16 World Health Organisation. Early detection of occupational disease. Geneva: WHO, 1986.

17 Commission des Communautés Européennes-CECA. Aidemémoire pour la pratique de l'examen de la fonction ventilatoire par la spirographie. Luxembourg: Collection D'Hygiene et de Medicine du Travail, No 11:1971.

18 Cherniack RM, Raber MB. Normal standards for ventilatory function using an automated wedge spirometer. Am Rev Respir Dis 1972;106:38-46.

19 Barbero CA, Flores R. Estudios sobre cannabosis: monographia de enfermedades profesionales. Madrid: Instituto Nacional de Medicina y Seguridad del Trabajo, 1948.

20 Barbero CA, Flores R. Dust disease in hemp workers. Arch Environ Health 1967;14:529-32.

21 Zuskin E, Skuric Z, Kanceljak B, Pokrajac D, Schachter EN, Witek TJ. Respiratory symptoms and ventilatory capacity in soy bean workers. Am J Ind Med 1988;14:157-65.

22 Beck GJ, Schachter EN, Maunder RL, Schilling RSF. A prospective study of chronic lung disease in cotton textile workers. Ann Intern Med 1982;97:645-51.

23 Beck GJ, Schachter EN. The evidence for chronic lung disease in cotton textile workers. American Statistician 1983;37:404-12.

24 Beck GJ, Schachter EN, Maunder RL. Cotton dust and smoking effect on lung function in cotton textile workers. Am J Epidemiol 1984;119:33-43.

25 Rylander R, Haglind P. Exposure to cotton workers in an experimental cardroom with reference to airborne endotoxins. Environ Health Perspect 1986;66:83-6.

26 Buck MG, Wall JH, Schachter EN. Airway constrictor response to cotton bract extracts in the absence of endotoxin. $\mathrm{Br} J$ Ind Med 1986;43:220-6.

Accepted 19 February 1990 